\title{
41SM32 on Little Saline Creek in Smith County, Texas
}

Timothy K. Perttula

Heritage Research Center, Stephen F. Austin State University

Mark Thaker

Follow this and additional works at: https://scholarworks.sfasu.edu/ita

Part of the American Material Culture Commons, Archaeological Anthropology Commons, Environmental Studies Commons, Other American Studies Commons, Other Arts and Humanities Commons, Other History of Art, Architecture, and Archaeology Commons, and the United States History Commons

Tell us how this article helped you.

This Article is brought to you for free and open access by the Center for Regional Heritage Research at SFA ScholarWorks. It has been accepted for inclusion in Index of Texas Archaeology: Open Access Gray Literature from the Lone Star State by an authorized editor of SFA ScholarWorks. For more information, please contact cdsscholarworks@sfasu.edu. 


\section{SM32 on Little Saline Creek in Smith County, Texas}

Creative Commons License

(c) (i) (8)

This work is licensed under a Creative Commons Attribution-NonCommercial 4.0 International License 


\title{
41SM32 on Little Saline Creek in Smith County, Texas
}

\author{
Timothy K. Perttula and Mark Thacker
}

\section{INTRODUCTION}

A review of early trinomial numbers for sites located in Smith County in East Texas indicated that between 1938 and 1943 Jack Hughes identified and collected from at least 37 sites listed on the Texas Historic Site Atlas. From 1938 to 1941 his site locations randomly occur throughout the County; interestingly there are no sites recorded in 1942. In 1943 he recorded about 14 sites along Black Fork Creek and its tributaries, this being mostly west of the City of Tyler.

The primary purpose in reviewing the available archaeological information about these early recorded sites was to re-visit selected sites if necessary and to update information that was recorded beginning almost 80 years ago. An entry contained on a Texas Archeological Research Laboratory at The University of Texas (TARL) site card indicated that Hughes collected artifacts from a site (41SM32) located on Little Saline Creek, near the much better known Alligator Pond site (41SM442) (Perttula and Walters 2012; Perttula and Thacker 2014a, 2014b) that had been recorded in 2011 by Mark Walters. The Alligator Pond site is on property owned by Thacker, a Texas Archeological Stewardship Network member.

41SM32 is a prehistoric archaeological site that was found and recorded in September 1940 by Jack Hughes, who later went on to a career as a professional archaeologist in Texas. The site is on Little Saline Creek, a northward-flowing tributary to the Sabine River about $10 \mathrm{~km}$ to the north, in the Post Oak Savannah of East Texas (Figure 1).

\section{SITE INVESTIGATIONS}

The limited notes accompanying the collections from 41SM32 at TARL indicate that the site is along the west bank of Little Saline Creek several hundred yards north of the road between Tyler State Park and Highway 37 (the Tyler-Lindale Highway), now County Road 431. The presumed site area has slopes of 3-8 percent, with a small amount of semi-level ground about 80 meters west of the creek. Soils along the creek floodplain are Keechi Loam and Mantachie, while the soils at 41SM32 are Gallime fine sandy loam.

The notes do not specify, but we suspect that the artifacts collected at 41SM32 by Hughes came from a surface collection of exposed artifacts in a field along Little Saline Creek. There is no information available on the size of the site.

\section{ARTIFACT ASSEMBLAGE}

The TARL collections from 41SM32 include several chipped stone tools and tool fragments as well as 54 sherds from ancestral Caddo plain ware, utility ware, and fine ware vessels.

There are four bifaces or biface fragments in the collection; three of these were likely discarded in the process of manufacturing dart points. Two are made from quartzite and one is made from petrified wood. 


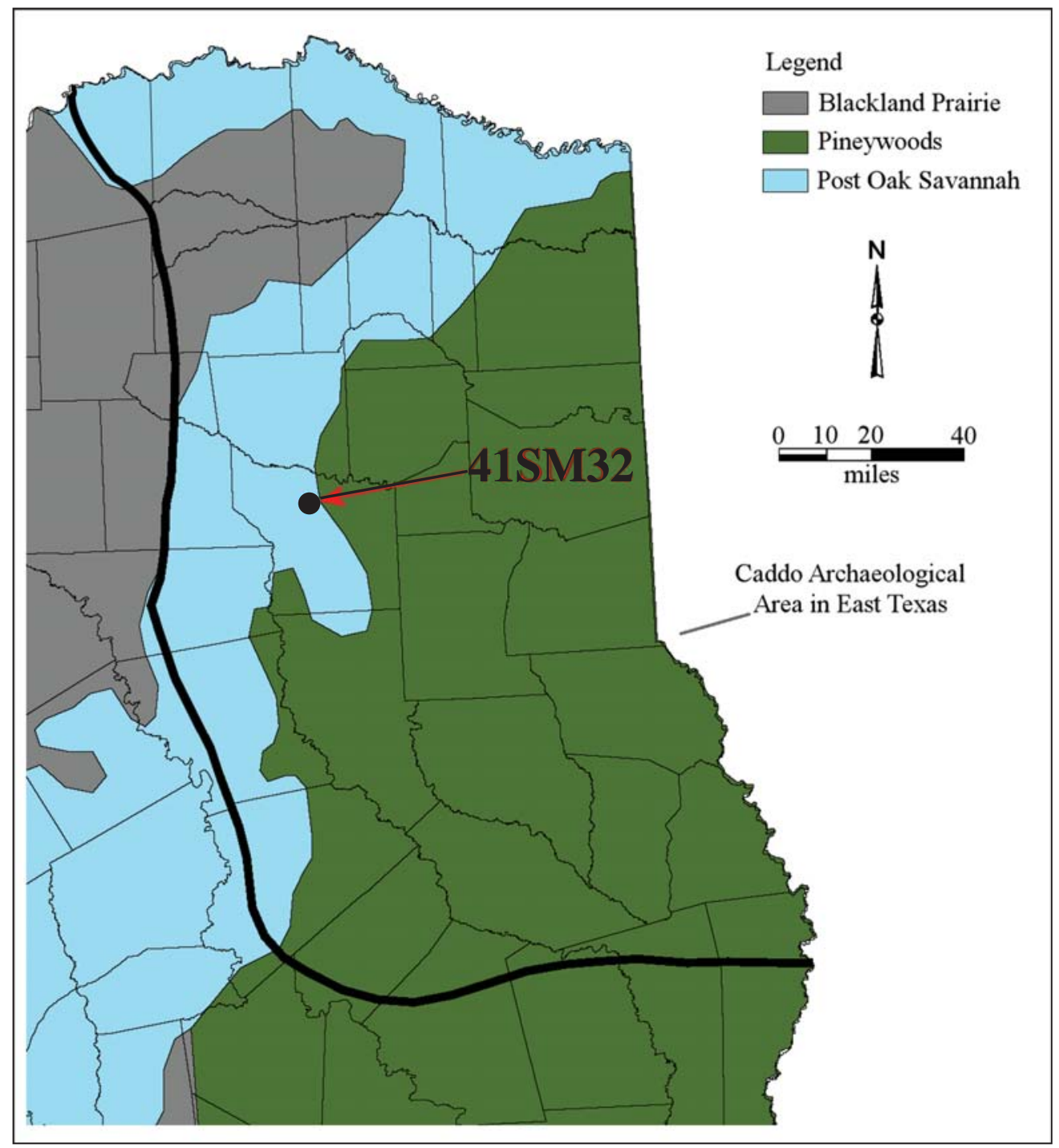

Figure 1. The location of 41SM32 in East Texas.

The other biface is a large fragment made from ferruginous sandstone; this may have been a large knive or saw. All three lithic raw materials represented in the bifaces are available locally. There is one expedient flake tool on a non-local light gray chert; the tool has retouch/use-wear along two sides of the flake.

The remaining chipped stone tools are dart points of Late Archaic (ca. 5000-2500 years B.P.) and Woodland (ca. 2500-1150 years B.P.) period age. They include a mid-section fragment of petrified wood, a possible Late Archaic Bulverde point (expanding stem, flat to slightly concave base, no barbs, and a resharpened blade) made on gray chert, and three Woodland period dart points: one Kent (petrified wood), one Gary (petrified wood), and a Godley (quartzite). The stem width of the one Gary point is only $11.5 \mathrm{~mm}$, suggesting this is a later variety of Gary, probably made between ca. A.D. 200-700.

The ceramic sherds from 41SM32 are from plain ware ( $n=23,43$ percent), utility ware ( $n=30,55$ percent), and fine ware ( $\mathrm{n}=1,2$ percent) vessels (Table 1 ). The vessels from all three wares are primarily tempered with grog (91 percent), and only 9 percent of the sherds are from bone-tempered vessels. The plain to decorated sherd ratio in this small sherd assemblage is 0.74, suggesting a post-A.D. 1400 ancestral Caddo occupation. 
Table 1. Ceramic sherds from 41SM32.

\begin{tabular}{lccc}
\hline Ware & & Temper & N \\
& Grog & Bone & 23 \\
\hline Plain & 21 & 2 & 30 \\
Utility & 27 & 3 & 1 \\
Fine & 1 & - & 54 \\
\hline Totals & 49 & 5 & 54 \\
\hline
\end{tabular}

The decorated sherds from 41SM32 are overwhelmingly from utility wares, as they represent 97 percent of the sample of 31 decorated sherds from the site (Table 2). Only 3 percent of the sherds are from fine ware vessels.

Table 2. Decorated methods and decorative elements in the utility ware and fine ware sherds from $41 S M 32$.

$\begin{array}{llll}\begin{array}{l}\text { Decorative method/ } \\ \text { decorative element }\end{array} & \text { Rim } & \text { Body } & \text { N }\end{array}$

Utility Ware

\section{Brushed}

overlapping brushing marks

$\begin{array}{rrr}- & 2 & 2 \\ - & 13 & 13 \\ - & 2 & 2\end{array}$

parallel brushing marks

vertical brushing marks

13

2

\section{Brushed-Incised}

parallel brushing and overlying curvilinear incised lines

\section{Brushed-Punctated}

parallel brushed-fingernail punctated

row through the brushing

\section{Incised}

parallel lines

\section{Incised-Punctated}

diagonal lines (R-L) and fingernail

1

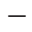

1

punctates in incised triangular zone

incised triangle filled with tool punctates

$$
-
$$

\section{Punctated}

fingernail punctated rows

tool punctated row
1

N

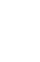


Table 2. Decorated methods and decorative elements in the utility ware and fine ware sherds from 41SM32, cont.

Decorative method/

$\operatorname{Rim}$

Body

$\mathrm{N}$

decorative element

Fine Ware

Engraved

horizontal line under the lip

1

$-$

1

Totals

4

27

31

$\mathrm{R}-\mathrm{L}=$ right-left; incised line begins at the right at the top of the rim and ends at the left at the bottom of the rim

About 57 percent of the utility ware sherds have brushing marks on them, and another 10 percent have brushed-incised (Figure 2a) or brushed-punctated decorative elements (see Table 2). These sherds are likely from Bullard Brushed jars. The considerable proportion of brushed sherds in the utility wares and the overall decorated sherd assemblage is consistent with a post-A.D. 1400 East Texas ceramic assemblage (Perttula 2015). It appears to be the case that the relative proportions of brushed utility wares increase through time in those areas where brushed vessels were made and used, such as the mid- Sabine, such that sherds with brushing marks may comprise as much as 90 percent of all the decorated sherds in some post-A.D. 1400 East Texas ceramic assemblages.

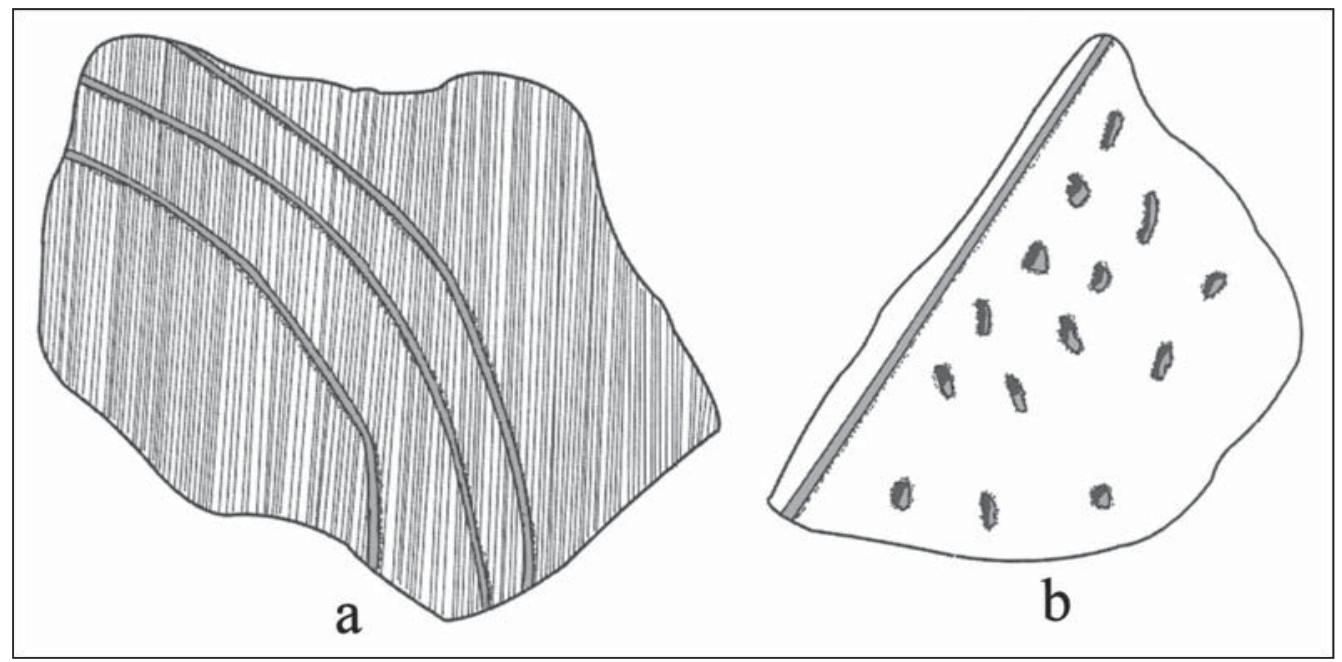

Figure 2. Selected decorative elements in utility ware sherds from 41SM32: a, brushedincised body sherd; b, incised-punctated lower rim sherd.

Sherds with rows of either fingernail or tool punctates comprise 23 percent of the utility ware sherds from 41SM32, as well as 75 percent of the utility ware rim sherds (see Table 2). These are from vessels of uncertain typology (see Suhm and Jelks 1962). The incised and incised-punctated (see Figure 2b) sherds from the site are likely from Maydelle Incised jars.

The one fine ware sherd from 41SM32 is a grog-tempered rim sherd. The rim has a single horizontal engraved line under the vessel lip. 


\section{SUMMARY AND CONCLUSIONS}

Site 41SM32 was identified and recorded by Jack Hughes in 1940 along the west bank of Little Saline Creek in northern Smith County, Texas. His small collection of artifacts indicates that the site was used to a limited extent in the Late Archaic and Woodland periods, probably for hunting activities and tool repair, as marked by several dart points made from local or non-local lithic raw materials. The principal occupation was by ancestral Caddo peoples, and it is likely that this occupation was year-round and perhaps lasted several years; there are probably remnants of Caddo structures preserved in the archaeological deposits at the site, along with the remains of broken and discarded ceramic vessels and other artifacts.

The Alligator Pond site (41SM442) (see Perttula and Walters 2012; Perttula and Thacker 2014a, 2014b) is on the east side of Little Saline Creek, about 200-250 meters from the suspected location of 41SM32. Given differences in the natural terrain, slope, and soils between the two sites, it is likely that the Alligator Pond would have been more conducive to farming and long-term settlement by Caddo peoples than would 41SM32.

The Alligator Pond site had been repeatedly used by aboriginal peoples from as early as ca. 6000 years B.P. until perhaps the 15th century A.D., similar to that of 41SM32. However, the decorated sherds from the site ( $n=376$, see Perttula and Thacker 2014b:Table 1) are consistent with a Caddo occupation that ended by ca. A.D. 1300, at least 100 years before 41SM32 was occupied by Caddo peoples. As an indication of the earlier age of the Alligator Pond site, given the suggested temporal relationship between the age of Caddo sites and the proportion of brushed sherds in decorated sherd assemblages in much of East Texas, only 10.4 percent of the decorated sherds are from brushed vessels at the Alligator Pond site compared to 64 percent of the decorated sherds from 41SM32.

Hopefully 41SM32 can be relocated. If so, additional investigations (surface collections and intensive shovel testing) may be warranted to obtain more detailed information about the character of the ancestral Caddo occupation there.

\section{ACKNOWLEDGMENTS}

Thanks to Jonathan Jarvis and Jean Hughes of the Texas Archeological Research Laboratory at The University of Texas and Austin for facilitating access to the collections and records from 41SM32. Lance Trask prepared the figures for this article.

\section{REFERENCES CITED}

Perttula, T. L.

2015 East Texas Caddo Ceramic Sherd Database. Journal of Northeast Texas Archaeology 51:1-46.

Perttula, T. K. and M. Thacker

2014a Analysis of New Artifact Collections from Archaic to Ancestral Caddo Sites in the Saline Creek Basin in Northern Smith County, Texas. Journal of Northeast Texas Archaeology 43:1-25.

2014b Additional Collections of Woodland to Caddo Period Artifacts from the Alligator Pond Site (41SM442), Smith County, Texas. Journal of Northeast Texas Archaeology 46:1-5.

Perttula, T. K. and M. Walters

2012 Caddo Sites in the Saline Creek Basin in Northern Smith County, Texas. Journal of Northeast Texas Archaeology 36:47-63.

Suhm, D. A. and E. B. Jelks (editors)

1962 Handbook of Texas Archeology: Type Descriptions. Special Publication No. 1, Texas Archeological Society, and Bulletin No. 4, Texas Memorial Museum, Austin. Reprinted in 2009, Gustav's Library, Davenport, Iowa. 